\title{
Characteristics of an Altered Diabase Dike in a Coal Seam: A Case Study from the Datong Coalfield, Shanxi, China
}

\author{
Xiaoxia Song $D^{1,2}$ Kaijie Li, ${ }^{1}$ Hongtao Ma, ${ }^{1}$ Dongna Liu, ${ }^{1,2}$ Jingui Zhao, ${ }^{1,2}$ and Jiarui Zhou ${ }^{1}$ \\ ${ }^{1}$ Department of Geosciences and Engineering, Taiyuan University of Technology, Taiyuan 030024, China \\ ${ }^{2}$ Shanxi Key Laboratory of Coal and Coal Measures Gas Geology Exploration, Taiyuan 030024, China
}

Correspondence should be addressed to Xiaoxia Song; songxiaoxia@tyut.edu.cn

Received 27 November 2019; Revised 27 January 2020; Accepted 12 February 2020; Published 7 July 2020

Academic Editor: Mohammad Sarmadivaleh

Copyright (C) 2020 Xiaoxia Song et al. This is an open access article distributed under the Creative Commons Attribution License, which permits unrestricted use, distribution, and reproduction in any medium, provided the original work is properly cited.

Carboniferous-Permian coal seams in the Datong coalfield are intruded by Mesozoic magmatic dikes and sills. Our observations indicate that these dikes and sills have been seriously altered and have lost their original characteristics. Although this phenomenon has been mentioned in some studies, there is a lack of detailed research on the alteration mechanism. To fill this research gap, six dike samples were collected in this study to analyze their alteration characteristics and mechanisms. Petrographic analysis, scanning electron microscopy, and X-ray diffraction were used to determine the mineralogy of the altered igneous samples. The results suggest that the mineral alteration is associated with severe carbonation and clavization. The carbonation of mafic minerals is due to the release of $\mathrm{CO}_{2}$ generated from the coking of high volatile bituminous coals that may have occurred during the intrusive event. However, labradorite did not react with $\mathrm{CO}_{2}$. The water activity in the coal seam was enhanced by the dikes, and mafic minerals were converted into mixtures of chlorite and smectite group minerals. The water activity is especially high at the edges of the dike. Albite and clay minerals were formed due to the albitization of labradorite. Based on these effects, the dike can be divided into weak alteration, carbonation, and clavization bands. The alteration processes in the coal seam are described in detail in this work, and potential formation mechanisms are suggested.

\section{Introduction}

Igneous intrusions in coal seams have been reported for many coalfields, for example, coalfields in the United States [1-3], Australia [4-6], China [7, 8], and India [9-11]. A large body of literature is available regarding the contact metamorphism of coal. However, the alteration characteristics of intrusive bodies in coal seams have rarely been discussed. Kisch and Taylor reported the alteration of an andesite sill in the Collinsville coalfield [4] and that of a basanite sill in Baralaba [5], Australia. The intrusive bodies turned white after entering the coal seam and were thus named "White traps." Petrological and mineralogical analyses of the altered intrusions suggested that the porphyry in the intrusive rocks consists of plagioclase, while the matrix contains kaolinite, chert, siderite, ankerite, and calcite. Plagioclase crystals near the coal/rock contact zone were altered to clay minerals, and mafic minerals were converted into carbonate minerals. These changes may be related to the release of $\mathrm{CO}_{2}$ from the coal. Ward et al.observed dike zoning while studying the impact of a diabase dike on a coal seam in Belmont, New South Wales, Australia [6]. Pyroxene was altered to biotite and chlorite, while plagioclase did not undergo alteration in the central part of the dike (fresh, dark green in color). Dolomite, siderite, chlorite, and montmorillonite were the dominant minerals at the edges of the dike (altered, pale brown in color). Chen reported changes in the color of the upper part of the sill near the coal seam in the Huainan coal mine, China [8], and suggested that this phenomenon is a result of changes in the lithology of the upper sill. The migration of silicate minerals from the lower part of the sill to the upper part may have resulted in the formation of light-colored granodiorite. Although color changes associated with igneous intrusions in coal seams have been reported in the above-mentioned studies, alteration mechanisms have rarely been discussed. The aim of the current study was to elucidate the alteration mechanisms in igneous dikes in the Datong coalfield. 


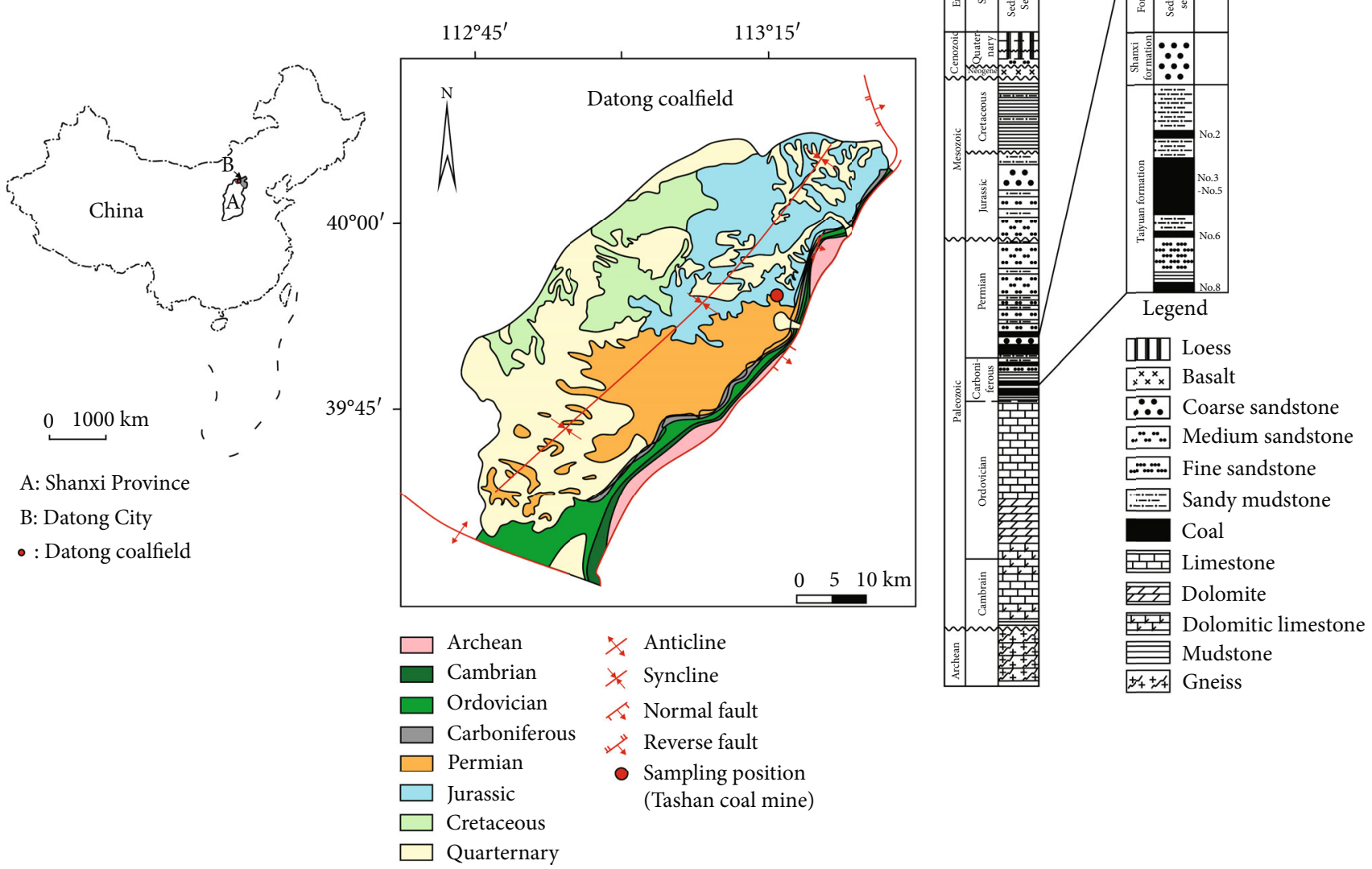

FIGURE 1: Location, geological map, and generalized stratigraphic column of the Datong coalfield.

During the exploration and mining of CarboniferousPermian coal seams in the Datong coalfield, basic-ultrabasic lamprophyre, carbonatite $(229 \pm 11 \mathrm{Ma})$ [12-15], and diabase (115-140 Ma) [16, 17] were encountered. These intrusions occur mainly as dikes and sills. The most notable feature of these intrusions is that they mainly are light gray or pale yellow (Figure 14-17 in the Supplementary Material), in contrast to typical lamprophyre or diabase (Figure 18 in the Supplementary Material). As mentioned previously, this phenomenon was also reported in Queensland, New South Wales, Australia, and Huainan, China. Our aim was to determine the responsible alteration mechanisms using several analytical techniques.

\section{Geologic Setting}

The Datong coalfield is located in the northern part of the Shanxi Province, China, and is $\sim 50 \mathrm{~km}$ long (NE-SW) and $30 \mathrm{~km}$ wide (NW-SE), covering a total area of $1828 \mathrm{~km}^{2}$. The coalfield is bounded by the Qingciyao fault to the northeast, Kouquan fault to the south and southeast, and Hongtaoshan anticline to the southwest. The northwest is the predicted denudation boundary of the coal seam [16-21] (Figure 1). The base of the Datong coalfield consists of an Archaean gneiss. Cambrian strata mainly consist of mudstones, limestones, and dolomites and have an angular unconformity with the Archaean strata. The Ordovician strata include limestones, dolomites, and dolomitic limestones and are conformable with the lower Cambrian strata. Due to Caledonian tectonic movement, the Upper Ordovician, Silurian, Devonian, and Lower Carboniferous strata are absent. Coal in the Datong Basin is mainly found in the Taiyuan and Shanxi formations in the Upper Carboniferous-Lower Permian system. Due to collisions between the North China Craton and Siberian plates, intense magmatism occurred during the Triassic period [22]. The Datong coalfield, located at the northern margin of the North China Craton, is intruded by basic-ultrabasic lamprophyres and carbonatites [12]. The Yanshan tectonic movement during the Late Jurassic to Early Cretaceous periods also affected the Datong coalfield; the coal seam is intruded by diabase. Furthermore, magmatic activity is mainly concentrated in faulted areas in the central and northern regions of the coalfield, where dikes and sills occur.

\section{Samples and Methods}

3.1. Samples. Rock samples (TS2-TS5), mixed coal-rock samples (TS1 and TS6), natural coke samples (TS7-TS9), and normal coal samples (TS10 and TS11) were collected from a diabase dike and from the surrounding area (Figure 2). Samples TS10 and TS11 were collected 10 and $20 \mathrm{~m}$ away from the coal/dike contact zone, respectively. 

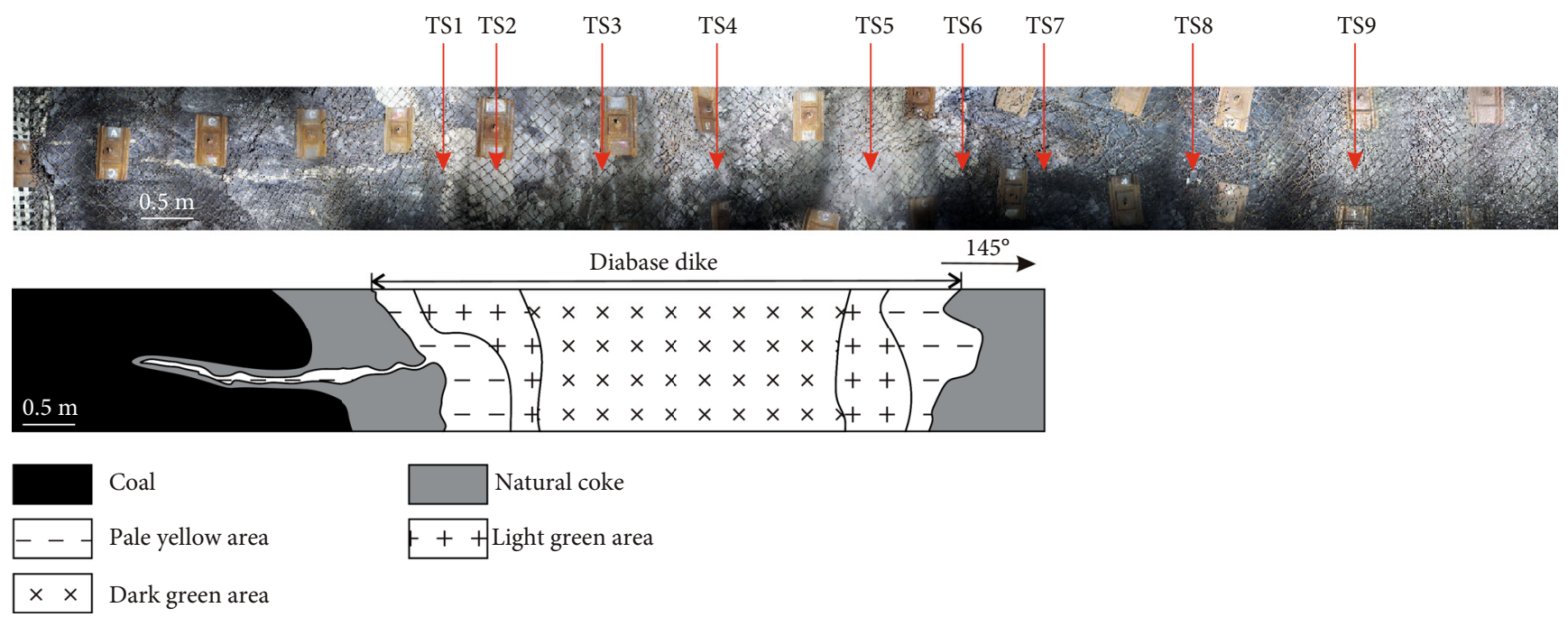

Figure 2: Photo and macroscopic characteristics of the dike. The sampling positions are marked. Sample TS10 was collected $10 \mathrm{~m}$ away from the dike, and TS11 was collected $20 \mathrm{~m}$ away from the dike.

3.2. Methods. Macro-observations were made on samples TS1-TS6. A LEICA S9i stereo microscope (6-55x) was used to determine the macro-characteristics of these samples. Thin sections of samples TS2-TS5 were examined using a LEICA DM2700P transmitted light microscope. Sample mineral compositions were determined by random point counting on photomicrographs using the JMicrovision software.

The mineral morphologies of TS2-TS5 were semiquantitatively analyzed using a TESCAN-MIRA3 cold-field emission scanning electron microscope (SEM) with an energy-dispersive spectrometer (EDS, Oxford-X-MaxN20, $\mathrm{Si}$ (Li) detector). The spectra were analyzed using the AZtecEnergy software (Oxford Instruments). The mineral composition of samples TS2-TS5 was determined with an X-ray diffractometer (XRD; Rigaku SmartLab X) using $\mathrm{Ni}$-filtered $\mathrm{Cu}-\mathrm{K} \alpha$ radiation at $18 \mathrm{~kW}$ and a scintillation detector. The XRD patterns were recorded in a $2 \theta$ range of $3^{\circ}-60^{\circ}$ with a step size of $0.02^{\circ}$. The initial data, HighScore Plus software, and ICDD PDF database were used to identify the mineral composition.

Random vitrinite reflectance ( $\mathrm{VRr}$ ) spectra of samples TS6-TS11 were recorded using a LEICA DMC4500 reflected light microscope and BRICC-M2 automatic test system (based on the Chinese National Standard GB/T 6948-2008 [23]). The coal quality parameters, including proximate (i.e., moisture, ash yield, volatile matter, and fixed carbon) and ultimate (C, $\mathrm{H}, \mathrm{O}$, and $\mathrm{N}$ ) analyses, were determined according to Chinese National Standards GB/T212-2008 [24] and GB/T476-2001 [25] and using the same procedures as reported in ASTM D3173-03 [26], ASTM D3174-04 [27], ASTM D3175-02 [28], and ASTM D3178-89 [29], except for small temperature differences $\left(815^{\circ} \mathrm{C} \pm 10^{\circ} \mathrm{C}\right.$ and $700-750^{\circ} \mathrm{C}$ for $\mathrm{A}_{\mathrm{ad}}, 105^{\circ} \mathrm{C}-110^{\circ} \mathrm{C}$ and $104-110^{\circ} \mathrm{C}$ for $\mathrm{M}_{\mathrm{ad}}$, and $600^{\circ} \mathrm{C}-850^{\circ} \mathrm{C}$ and $500^{\circ} \mathrm{C}-900^{\circ} \mathrm{C}$ for $\mathrm{C}_{\mathrm{ad}}$ and $\mathrm{H}_{\mathrm{ad}}$ based on the Chinese National and ASTM standards, respectively).

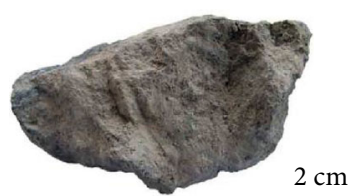

(a)

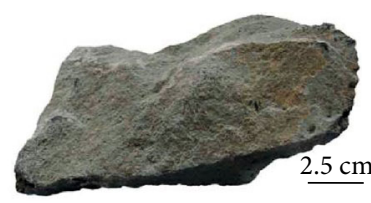

(c)

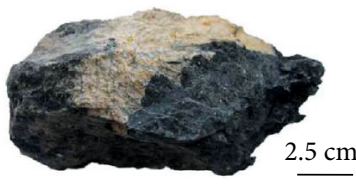

(b)

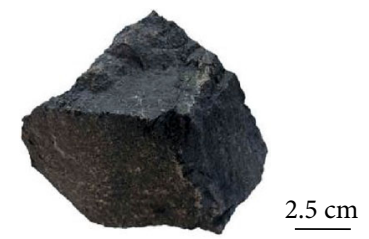

(d)

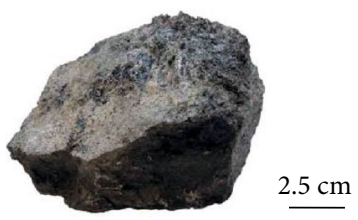

(e)

FIgURE 3: Photo of the igneous rock samples. (a) TS2. (b) TS6 (coal and rock mixed). (c) TS5. (d) TS3. (e) TS4.

\section{Results}

4.1. Field Observations and Macroscopic Characteristics of the Samples. The average width of the dike is $4.6 \mathrm{~m}$; it gradually widens upward. The dike exhibits notable color changes on the macroscopic scale. The micrographs can be roughly divided into three bands (Figure 2), which from the edge to the middle of the dike are: pale yellow, light green, and dark green.

(1) The pale yellow band is located $50-70 \mathrm{~cm}$ from the edge of the dike. The hand specimen is pale yellow, and the mineral particle size is less than $0.2 \mathrm{~mm}$, which is almost indistinguishable to the naked eye (Figures 3(a) and 3(b)). The minerals were 


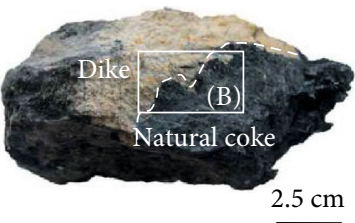

(a)

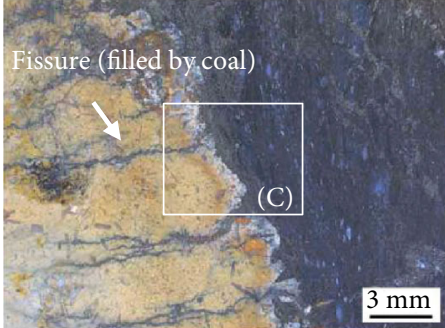

(b)

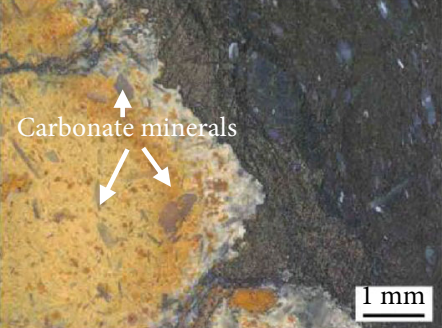

(c)

Figure 4: (a) Photo of sample TS6. (b) The coal liquefied and seeped into fissures at high temperature (stereomicroscopic images). (c) Carbonate minerals at the contact between the dike and natural coke (stereomicroscopic images).

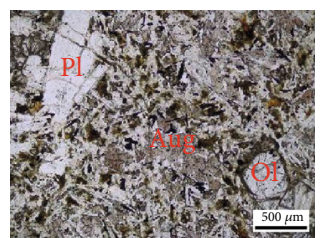

(a)

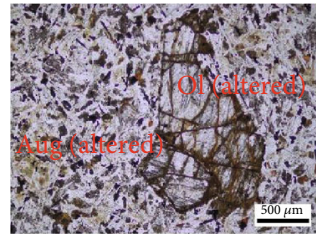

(e)

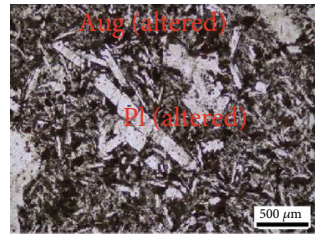

(i)

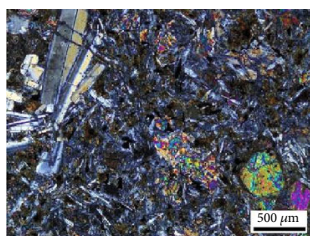

(b)

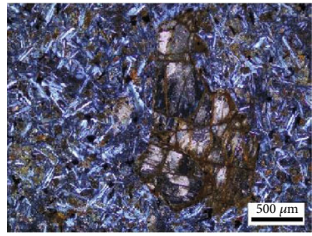

(f)

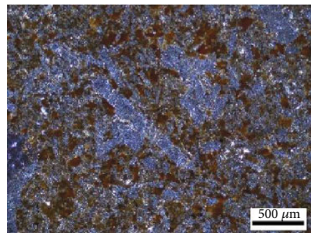

(j)

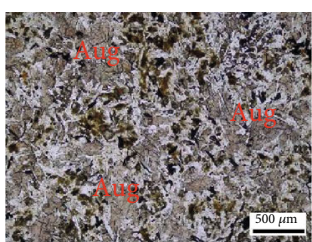

(c)

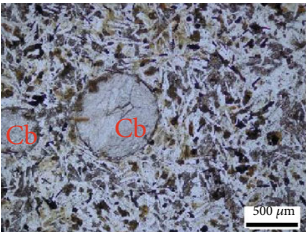

(g)

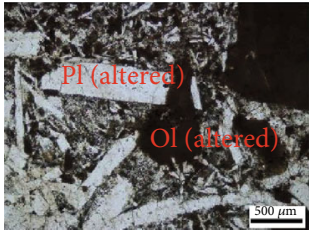

(k)

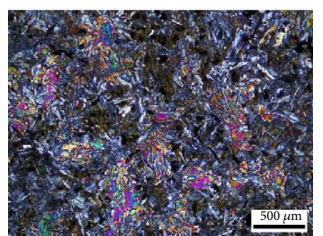

(d)

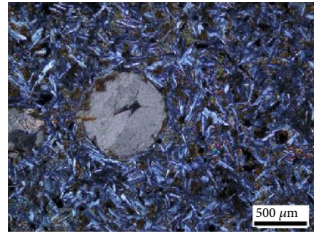

(h)

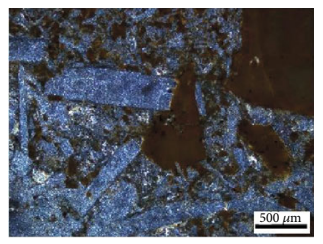

(l)

Figure 5: (a) Plane-polarized light (PPL), (b) cross-polarized light (XPL), (c) PPL, and (d) XPL photomicrographs of TS3. Euhedral plagioclase $(\mathrm{Pl})$, olivine $(\mathrm{Ol})$ (the cracks and margins of olivine changed into serpentine), and subhedral augite (Aug) were partially altered into chlorite and smectite. (e) PPL and (f) XPL photomicrographs of TS5. Augite was mostly converted into carbonate and mixtures of chlorite and smectite, while euhedral olivine was completely converted into carbonate minerals. (g) PPL and (h) XPL photomicrographs of TS5. Carbonate mineral spherulite (Cb). (i) PPL, (j) XPL, (k) PPL, and (l) XPL photomicrographs of TS2. Euhedral plagioclase was completely replaced by fine-grained clay minerals, and mafic minerals were completely converted into brown mixtures of chlorite, smectite, and carbonate minerals.

completely clavizated and reacted with dilute hydrochloric acid. Notably, a large amount of gray white and translucent carbonate minerals can be observed in the coal/rock contact zone. The coal that solidified after liquefaction fills the fissures of the magmatic rock (Figure 4)

(2) The light green band is $0.3-0.6 \mathrm{~m}$ wide. The hand specimen is light green and fine grained. The mineral particle size is $0.3-1.5 \mathrm{~mm}$, with an average size of $0.5 \mathrm{~mm}$ (Figure 3(c)). The plagioclase crystals are gray white and exhibit a subvitreous luster. Most of the pyroxene was altered. The unaltered pyroxene is dark green and has a vitreous luster.
The olivine crystals have diameters of $1-1.5 \mathrm{~mm}$ and were completely altered

(3) The dark green band at the center of the dike is 2.7$3 \mathrm{~m}$ wide. The hand specimen is dark green and fine grained. The mineral particles are $0.3-2 \mathrm{~mm}$ in size (average of $0.6 \mathrm{~mm}$; Figures $3(\mathrm{~d})$ and $3(\mathrm{e})$ ). The main minerals are pyroxene, plagioclase, and olivine. From a macroscopic perspective, almost no alteration occurred

4.2. Microscopic Characteristics of the Samples of Different Bands. The samples obtained from the dark green band display a porphyritic texture (Figures 5(a)-5(d)). The 
major phenocrysts include augite ( 28-43 vol\%, average of $31 \mathrm{vol} \%)$, plagioclase ( 27-46 vol\%, average of $37 \mathrm{vol} \%)$, and olivine $(\sim 3-8 \mathrm{vol} \%)$. The plagioclase crystals in the phenocrysts are $1-1.5 \mathrm{~mm}$ in size and euhedral. The extinction angles of the Carlsbad and albite twins indicate that the plagioclase is labradorite. Augite is the major mafic mineral. It is subhedral, pale green, and fills the gaps between the plagioclase crystals. Almost $30 \%-40 \%$ of the augite was converted into brown-green mixtures of chlorite and smectite. Olivine phenocrysts are $0.5-2 \mathrm{~mm}$ in size, euhedral, and colorless. The cracks and margins of the olivines were altered to serpentine. The matrix is fine and microcrystalline; only plagioclase and magnetite can be identified in the matrix.

The samples taken from the light green band exhibit a porphyritic texture. The major phenocrysts in these samples are augite ( $25-42 \mathrm{vol} \%$, average of $33 \mathrm{vol} \%)$, plagioclase ( $27-41 \mathrm{vol} \%$, average of $35 \mathrm{vol} \%)$, and olivine $(\sim 3-8$ vol\%). The major minerals in the light green area (TS5) are augite ( $37-44 \mathrm{vol} \%$, average of $42 \mathrm{vol} \%)$ and plagioclase ( $43-55 \mathrm{vol} \%$, average of $50 \mathrm{vol} \%)$. The minor minerals include olivine ( 3-8 vol\%), magnetite (3vol\%), and carbonate $(2 \mathrm{vol} \%)$. The labradorite crystals in the phenocrysts are $0.8-1.5 \mathrm{~mm}$ in size and euhedral. The augite in sample TS5 was altered to a greater extent than that in sample TS3; 70\% of the augite was converted to mixtures of chlorite and smectite and carbonate. The euhedral olivine phenocrysts are $1.5-2 \mathrm{~mm}$ in diameter and were replaced by carbonate minerals (maintaining the olivine crystal shape; the cracks and margins of the olivine were altered to serpentine; Figures 5(e) and 5(f)). Note that the sample contains many carbonate spherules $(0.4-1 \mathrm{~mm}$; Figures $5(\mathrm{~g})$ and $5(\mathrm{~h}))$. The matrix varies from fine grained to microcrystalline and plagioclase, magnetite, and carbonate minerals can be identified.

All minerals in the pale yellow band underwent severe alteration (Figures 5(i)-5(l)). Plagioclase in the phenocrysts and matrix was replaced by fine clay mineral particles and retained its crystalline morphology. Augite in this band was altered to a greater extent than that in sample TS5; all augites in this band were altered to dark brown carbonate and mixtures of chlorite and smectite. The euhedral olivine phenocrysts are $1.5-3 \mathrm{~mm}$ in diameter and were also altered to dark brown carbonate minerals and mixtures of chlorite and smectite (maintaining the olivine crystal shape).

The point counting method was used to evaluate the felsic mineral content of sample TS3. According to the QAP diagram of the IUGS [30], the lithology of this dike can be classified as diabase (Figure 6). The thin section indicates a porphyritic texture and euhedral plagioclase and subhedral augite. The olivine concentration is $\sim 5 \%$, indicating an olivine diabase porphyrite dike. A similar texture can be observed in the altered samples TS2 and TS5, which indicates that the entire dike has the same lithology, but different bands experienced different alteration processes.

Based on the SEM-EDS analysis of sample TS3 (Figures $7(\mathrm{a})$ and $7(\mathrm{~b})$ ), the mineral composition at point $c$

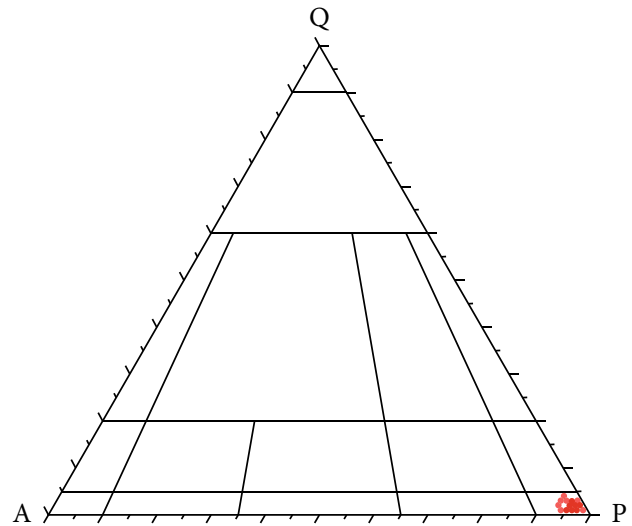

FIgURE 6: IUGS model classification of igneous rocks. The points were calculated based on point counting on thin sections. Q: quartz; A: alkali feldspar; P: plagioclase.

was altered; the main elements at this point are $\mathrm{Mg}, \mathrm{Al}, \mathrm{Fe}$, and Si (Figure 7(c)). The mineral composition indicates that it is augite, and its surface was gradually altered into fine schistose mixtures of chlorite and smectite (Figure $7(\mathrm{a})$ ). Almost no alteration can be observed at point $d$, and the EDS analysis indicates the lack of $\mathrm{Al}$ (Figure 7(d)), suggesting that the mineral at this point is olivine. The mineral texture at point $f$ is smooth, and the long columnar morphology was not altered. Based on the EDS analysis results, the ratio of silicon to aluminum is $\sim 2: 1$ (Figure $7(\mathrm{e})$ ). The mineral contains sodium and calcium (Figure $7(\mathrm{f})$ ), suggesting the inclusion of labradorite. Fluorapatite can be found as an accessory mineral at point $f$.

The degree of mineral alteration in sample TS5 is much higher than that of sample TS3 (Figures 8(a) and $8(\mathrm{~b}))$. The well-preserved mineral is labradorite, which exhibits almost no alteration (point $d$ ). Augite was almost completely altered (points $c$ and $e$ ). At a similar magnification, it was observed that augite in sample TS5 was altered to schistose mixtures of chlorite and smectite $(5-25 \mu \mathrm{m}$ in size; points $c$ and $e$ ). At the same time, many $10-15 \mu \mathrm{m}$ rhombic Ca-bearing $\mathrm{Mg}$-siderite crystals (point $f$ ) can be observed.

Sample TS2 was completely altered. The original mineral is absent and a large number of $2-5 \mu \mathrm{m}$ clay fraction grains, which are common alteration products of labradorite, can be observed (Figure 9(a)). Based on the EDS analysis results, the ratio of silicon to aluminum in the clastic minerals at point $c$ is $\sim 1: 1$ (Figure 9(d)), indicating that these are kaolin group clay minerals (1:1 clay mineral field). In sample TS6, kaolin group minerals (Figure 9(b)) and many Ca-bearing Mg-siderite crystals $(8-20 \mu \mathrm{m})$ can be observed (Figure 9(c)).

4.3. Mineralogy of the Samples of Different Bands. The alteration characteristics of the samples determined using macroscopic and microscopic methods correspond to the results of the XRD analysis (Figure 10). The XRD spectrum of sample TS3 is simple and characteristic peaks are notable, which suggests that the sample underwent very little 


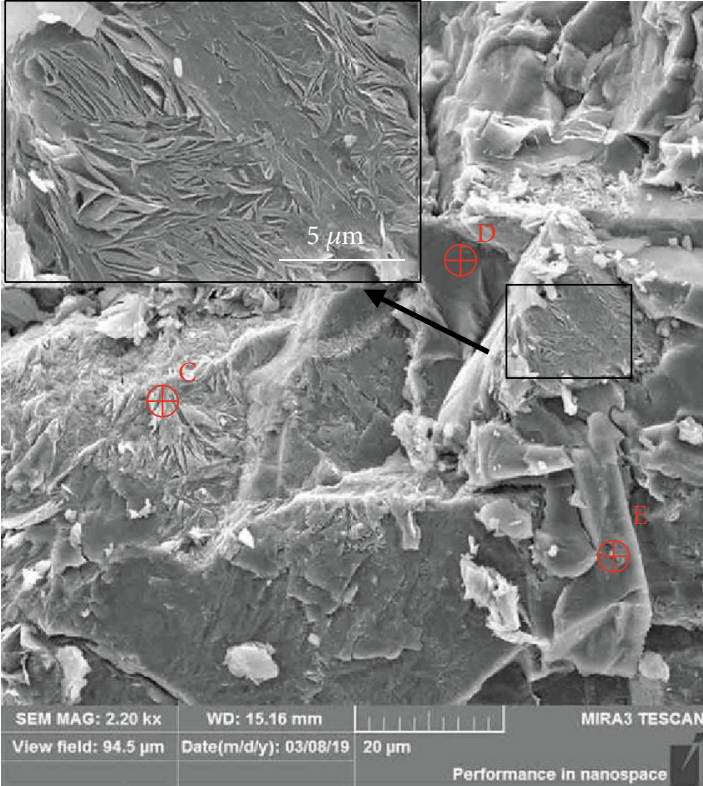

(a)

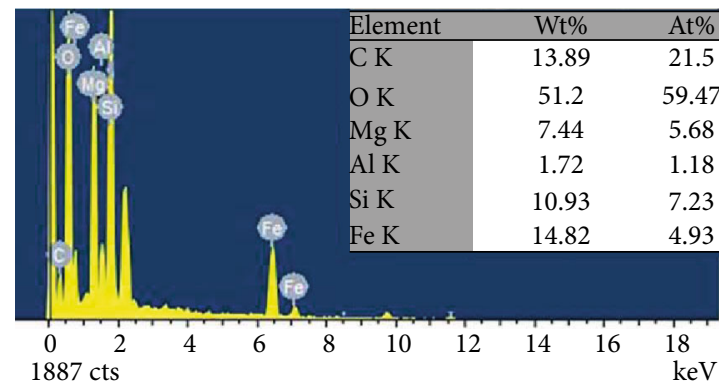

(c)

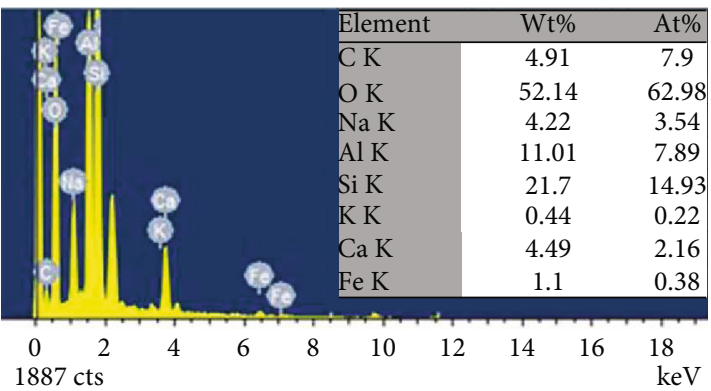

(e)

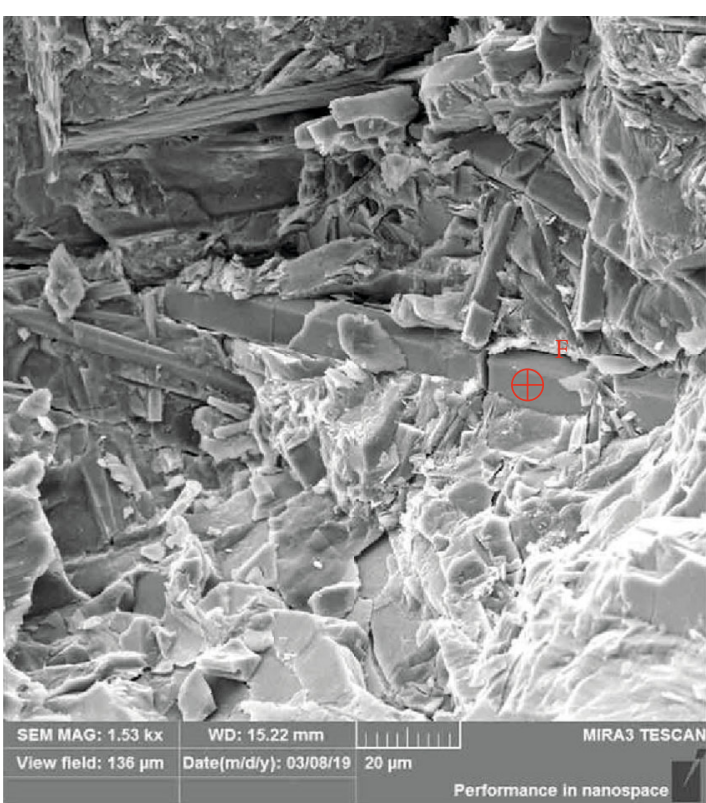

(b)

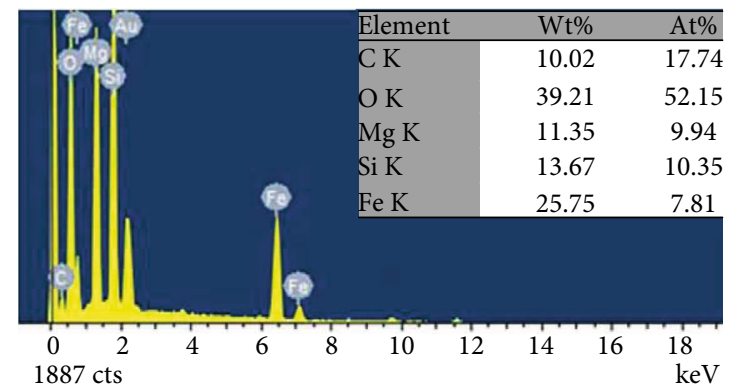

(d)

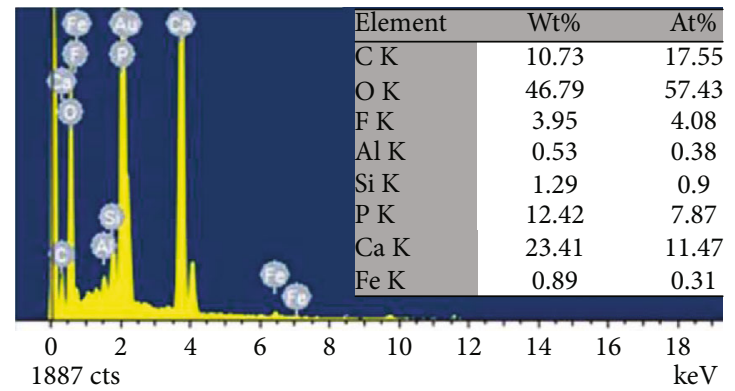

(f)

FIgURE 7: (a, b) SEM images of sample TS3 showing the EDS measurement points. (c-f) EDS patterns at the spots noted panels in (a) and (b).

alteration. Based on the intense reflections at $\sim 3.18 \AA$ and weaker reflections at $\sim 3.22$ and $\sim 3.73 \AA$, the most prominent mineral is labradorite. The other major mineral is augite, with an intense reflection at $\sim 2.98 \AA$ and weaker reflections at $\sim 2.93 \AA$ and $\sim 2.53 \AA$. The spectrum corresponding to sample TS5 shows that the main minerals are labradorite and augite. However, unlike sample TS3, the characteristic siderite peaks, that is, an intense peak at $\sim 2.79 \AA$ and weaker reflections at $\sim 3.58 \AA$ and $\sim 2.14 \AA$, are also present. In addition, the peak intensity of augite decreased. The spectrum corresponding to sample TS2 is very different from the spectra of the other two bands. This sample contains albite (intense peak at $\sim 3.23 \AA$ and weaker peaks at $\sim 4.11 \AA$ and $\sim 3.74 \AA$ ), siderite, and clay minerals. The intense reflections at $\sim 7.1 \AA$ and $\sim 3.56 \AA$ are representative of the kaolin group clay minerals. In general, the mixtures of chlorite and smectite group minerals yield intense peaks at $\sim 12 \AA$ and $\sim 14 \AA$ and can be observed in weathered magmatic rocks.

\section{Discussion}

Based on the results, we infer that the minerals in the samples from the middle to the edge of the dike experienced different 


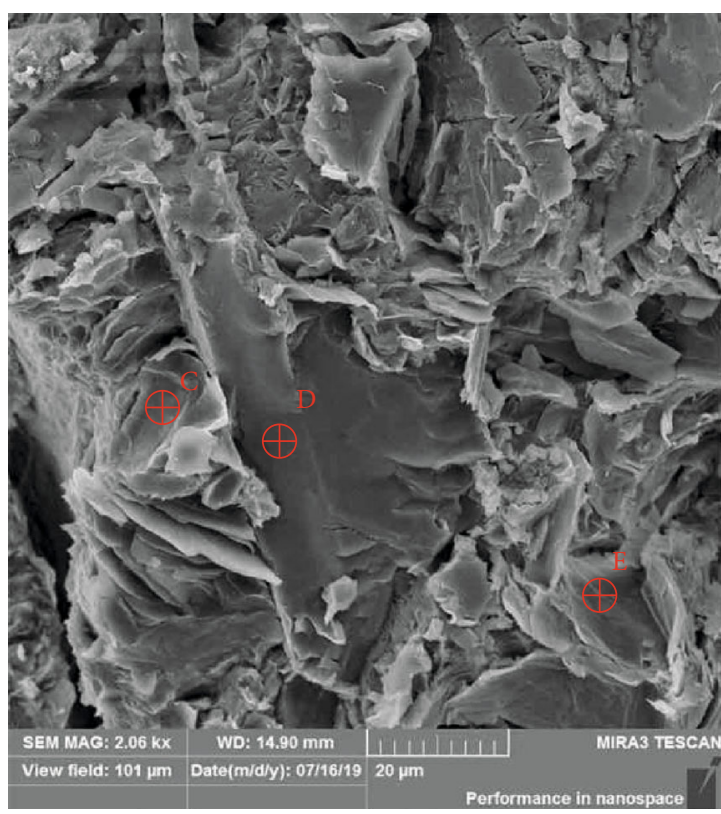

(a)

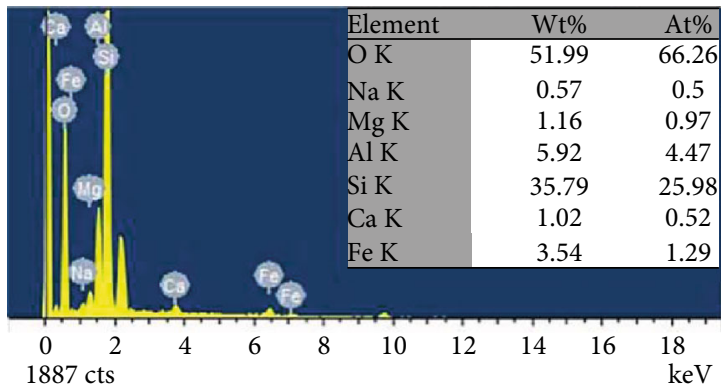

(c)

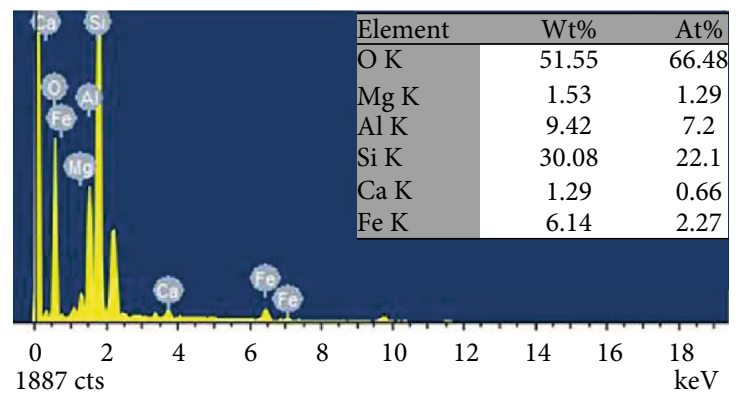

(e)

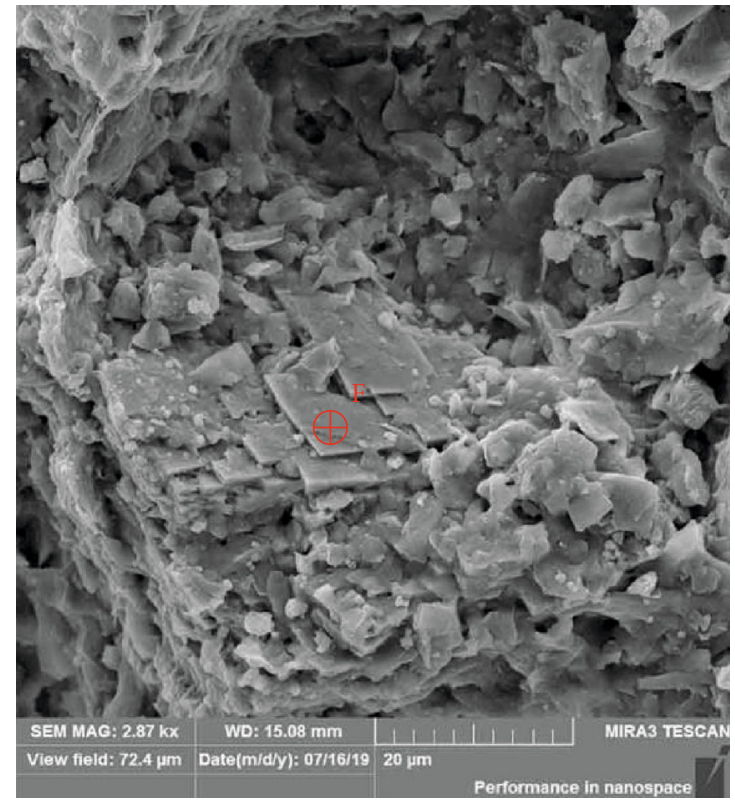

(b)

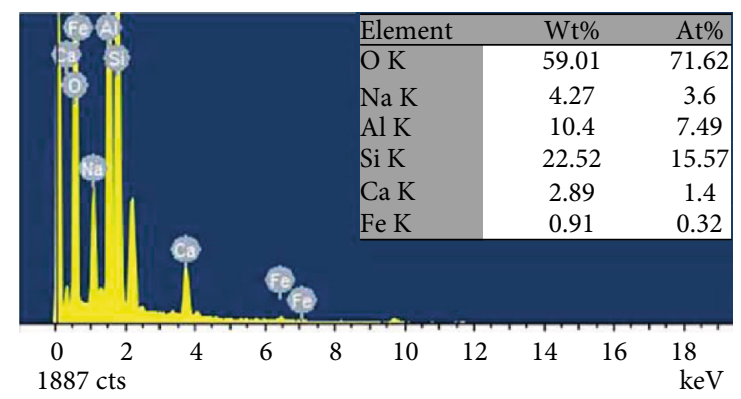

(d)

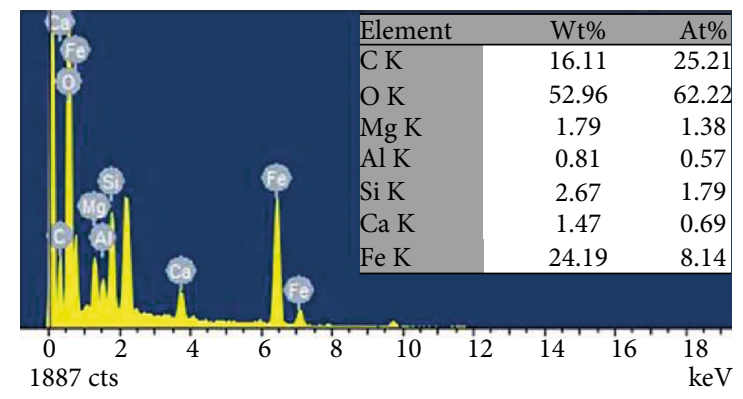

(f)

Figure 8: (a, b) SEM images of sample TS5 showing the EDS measurement points. (c-f) EDS patterns at the spots noted in panels (a) and (b).

levels and types of alteration, which resulted in different colors. The mineral alteration of this dike is discussed in this study from the perspective of the alteration of mafic minerals and plagioclase.

5.1. Dike Carbonation. Carbonation occurs at a distance of $1-1.5 \mathrm{~m}$ from the edge of the dike. Optical microscopy, SEM, and XRD data show that the pale yellow and light green bands contain many carbonate minerals. Based on Kisch [5], the carbonate production may be attributed to carbon dioxide generation from the coking of the coal seams at high temperature. Based on the normal coal $\mathrm{VRr}$ and quality data (Table 1) obtained, according to the ASTM D388-99 [31] protocol, it can be inferred that the unaffected coal near the dike is high volatile bituminous coal. Based on the coal quality of samples TS7 and TS8 near the contact zone (Table 1), coal affected by magma was altered to anthracite. Anisotropic macerals (mesophase spheres, mosaics, flow structure, and pyrolytic carbon), which are typical for natural coke $[10,11]$, can be observed under the microscope. Therefore, it can be assumed that the coal converted into natural coke. 


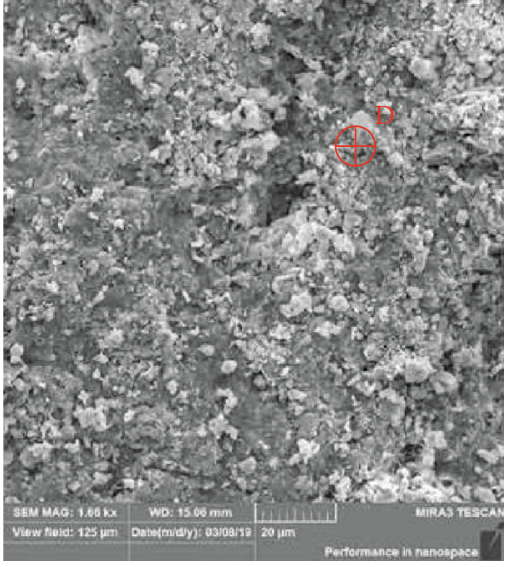

(a)

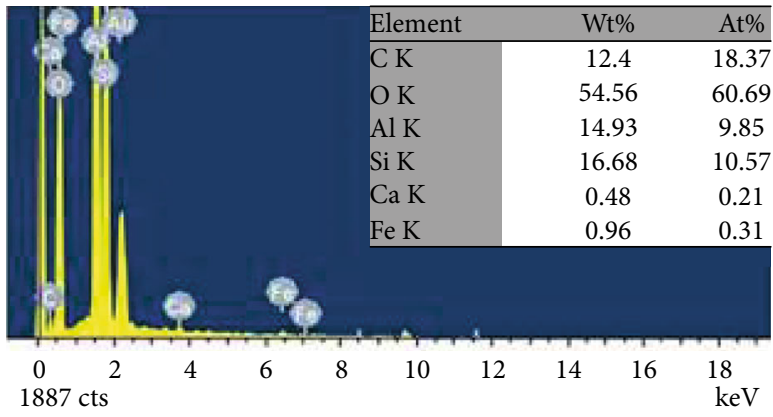

(d)

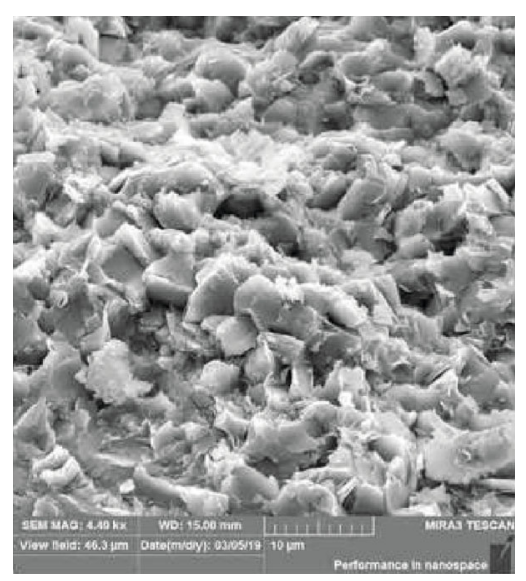

(b)

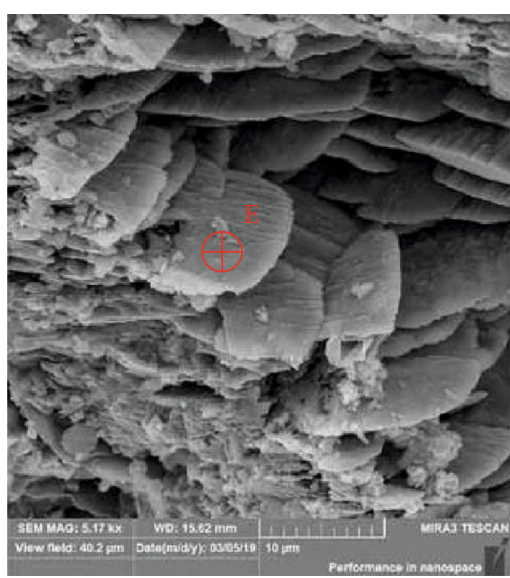

(c)

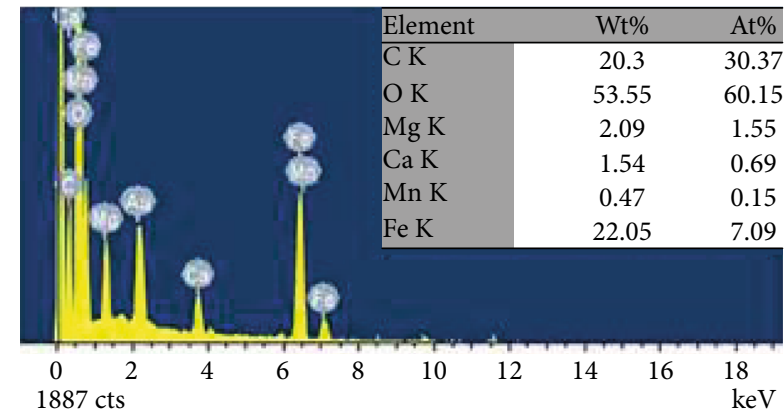

(e)

FIGURE 9: SEM images of samples TS2 (a) and TS6 (b, c) showing the EDS measurement points. (d, e) EDS patterns at the spots noted in panels (a) and (c).

When the coal was thermally influenced by magma, the volatile content decreased and the carbon content significantly increased, indicating that the coal experienced devolatilization $[1,3,5,32,33]$. The normal coal samples collected in this study are high volatile bituminous coal. When the coal rank increases rapidly, the release of volatile gas by devolatilization can be divided into two stages. In stage I ( $\mathrm{VRr}<1.2 \%)$, a large quantity of $\mathrm{CO}_{2}$ and a small amount of methane are released. In stage II ( $\mathrm{VRr}>1.2 \%)$, methane is produced $[5,34,35]$. The overall process based on which the coal rank rises can be summarized using the following equation [36]:

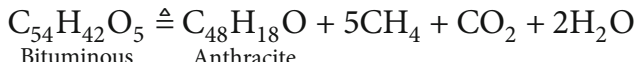

During this process, the gases are thought to migrate out of the rapidly heated coal because of the decreased gas adsorption ability of the metamorphosed coal. The excess gas is pushed into the surrounding lithologies [37, 38]. Mafic minerals have good $\mathrm{CO}_{2}$ absorption abilities and have been widely used for the absorption of artificial $\mathrm{CO}_{2}$ from the atmosphere [39, 40]. The conditions during magma intrusion in coal seams may be similar to those during artificial $\mathrm{CO}_{2}$ injection. The chemical formulas of the mafic minerals can be regarded as a combination of $\mathrm{MgO}, \mathrm{FeO}, \mathrm{CaO}$, and $\mathrm{NaO}+\mathrm{Al}_{2} \mathrm{O}_{3}$. In the presence of $\mathrm{CO}_{2}$, these compounds may undergo carbonation depending on the environmental conditions [41]. The temperature of the diabase intrusion is $\sim 1100^{\circ} \mathrm{C}-1200^{\circ} \mathrm{C}$, while the depth of the buried coal seam is $\sim 750-1000 \mathrm{~m}$ and the hydrostatic pressure is $\sim 75-100$ bar [10]. According to the spontaneous reaction conditions for minerals and $\mathrm{CO}_{2}$ summarized by Marini [41], the conditions for the spontaneous reaction of pyroxene and olivine with $\mathrm{CO}_{2}$ are met when the magma temperature is $350^{\circ} \mathrm{C}-400^{\circ} \mathrm{C}$ (Figure 11). Therefore, more carbonate minerals are formed at this stage. The corresponding reactions are as follows:

$$
\begin{aligned}
& \mathrm{Ca}(\mathrm{Mg}, \mathrm{Al})(\mathrm{Si}, \mathrm{Al})_{2} \mathrm{O}_{6}+\mathrm{CO}_{2} \rightarrow \mathrm{CaCO}_{3}+(\mathrm{Mg}, \mathrm{Fe}, \mathrm{Ca}) \mathrm{CO}_{3}+\mathrm{Al}^{3+}+\mathrm{SiO}_{2} \\
& \text { Augite Calcite } \mathrm{Ca} \text {-bearing } \mathrm{Mg} \text {-siderite } \\
& (\mathrm{Mg}, \mathrm{Fe})_{2} \mathrm{SiO}_{4}+\mathrm{CO}_{2}+\mathrm{H}_{2} \mathrm{O} \rightarrow \mathrm{Mg}_{6}\left[\mathrm{Si}_{4} \mathrm{O}_{10}\right](\mathrm{OH})_{8}+(\mathrm{Mg}, \mathrm{Fe}) \mathrm{CO}_{3} \\
& \text { Olivine } \quad{ }_{4} \quad \text { Serpentine } \quad \text { Siderite }
\end{aligned}
$$

Unlike the mafic minerals, labradorite does not undergo carbonation. Compared with the spontaneous reaction of plagioclase with $\mathrm{CO}_{2}$, the temperature required for the reaction between labradorite and $\mathrm{CO}_{2}$ is similar to the 

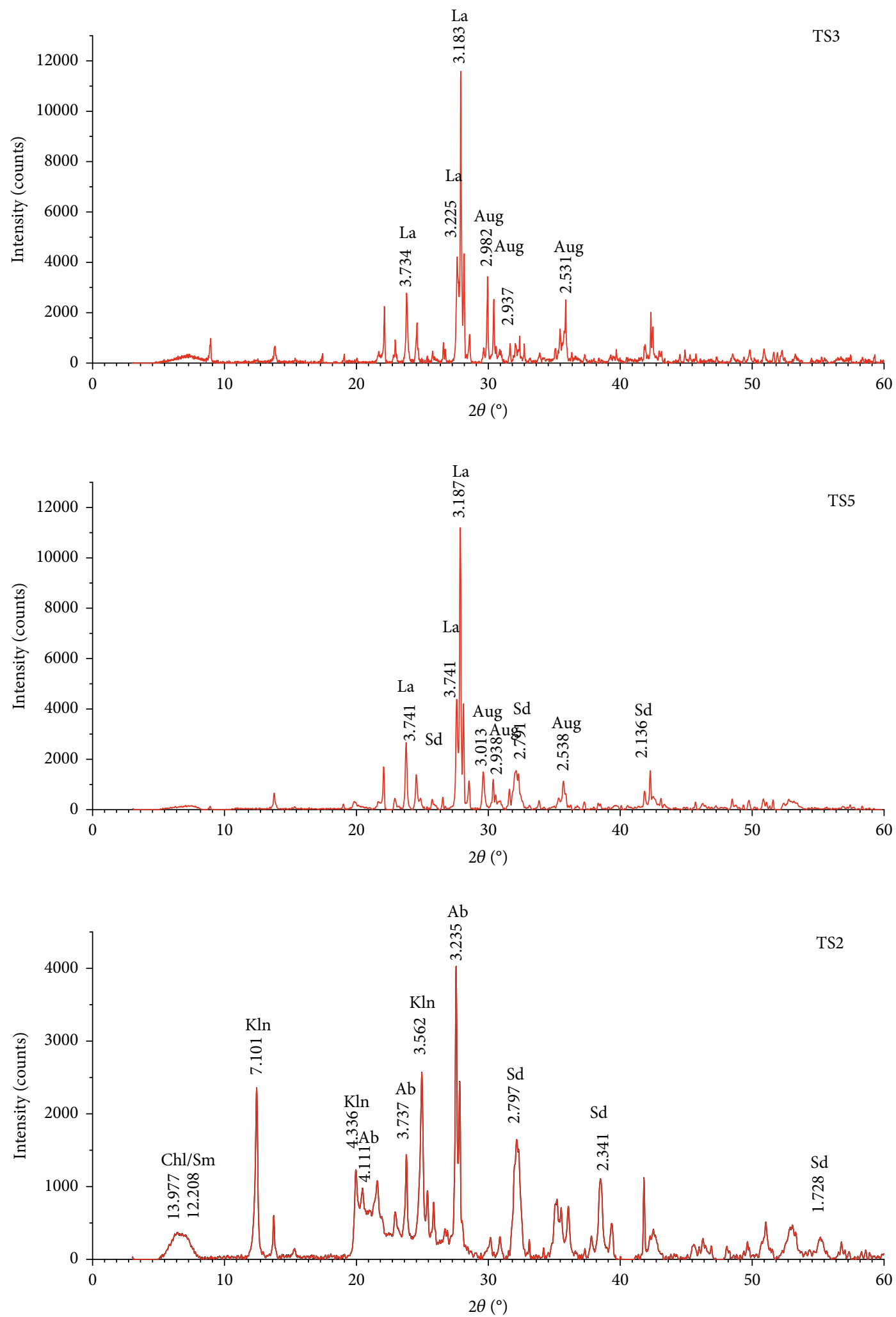

FIgURE 10: X-ray diffractograms of samples TS3, TS5, and TS2. La: labradorite; Aug: augite; Sd: siderite; Chl/Sm: mixtures of the chlorite and smectite groups; Kln: kaolin group; Ab: albite. 
TABLE 1: VRr results and proximate and ultimate analysis data of thermally altered coal and normal coal samples.

\begin{tabular}{|c|c|c|c|c|c|c|c|c|c|}
\hline \multirow{2}{*}{ Sample } & \multirow{2}{*}{$D(\mathrm{~m})$} & \multirow{2}{*}{$\operatorname{VRr}(\%)$} & \multicolumn{3}{|c|}{ Proximate analysis } & \multicolumn{3}{|c|}{ Ultimate analysis } & \multirow{2}{*}{ Category } \\
\hline & & & $\mathrm{M}_{\mathrm{ad}}(\%)$ & $A_{d}(\%)$ & $\mathrm{V}_{\mathrm{d}}(\%)$ & $\mathrm{C}_{\mathrm{daf}}(\%)$ & $\mathrm{H}_{\mathrm{daf}}(\%)$ & $\mathrm{N}_{\mathrm{daf}}(\%)$ & \\
\hline TS1 & 0.1 & - & 3.61 & 58.66 & 11.8 & 75.96 & 2.24 & 0.15 & Mixed coal and rock \\
\hline TS6 & 0.1 & 5 & 8.92 & 60.52 & 9.4 & 79.95 & 2.44 & 0.5 & Mixed coal and rock \\
\hline TS7 & 0.8 & 3.74 & 7.94 & 25.48 & 6.33 & 93.76 & 1.16 & 0.55 & Natural coke \\
\hline TS8 & 2 & 3.72 & 4.8 & 24.43 & 5.6 & 93.84 & 1.6 & 0.97 & Natural coke \\
\hline TS9 & 3.5 & 1.78 & 1.38 & 54.07 & 10.7 & 78.92 & 4.35 & 1.37 & Thermally altered coal \\
\hline TS10 & 10 & 0.75 & 1.98 & 15.2 & 33.9 & 83.34 & 4.88 & 1.4 & Normal coal \\
\hline TS11 & 20 & 0.76 & 1.79 & 27.05 & 31.4 & 81.97 & 4.48 & 1.34 & Normal coal \\
\hline
\end{tabular}

D: distance to intrusion; M: moisture; A: ash; V: volatile matter; Ad: air-dried basis; d: dry basis; daf: dry ash-free basis.

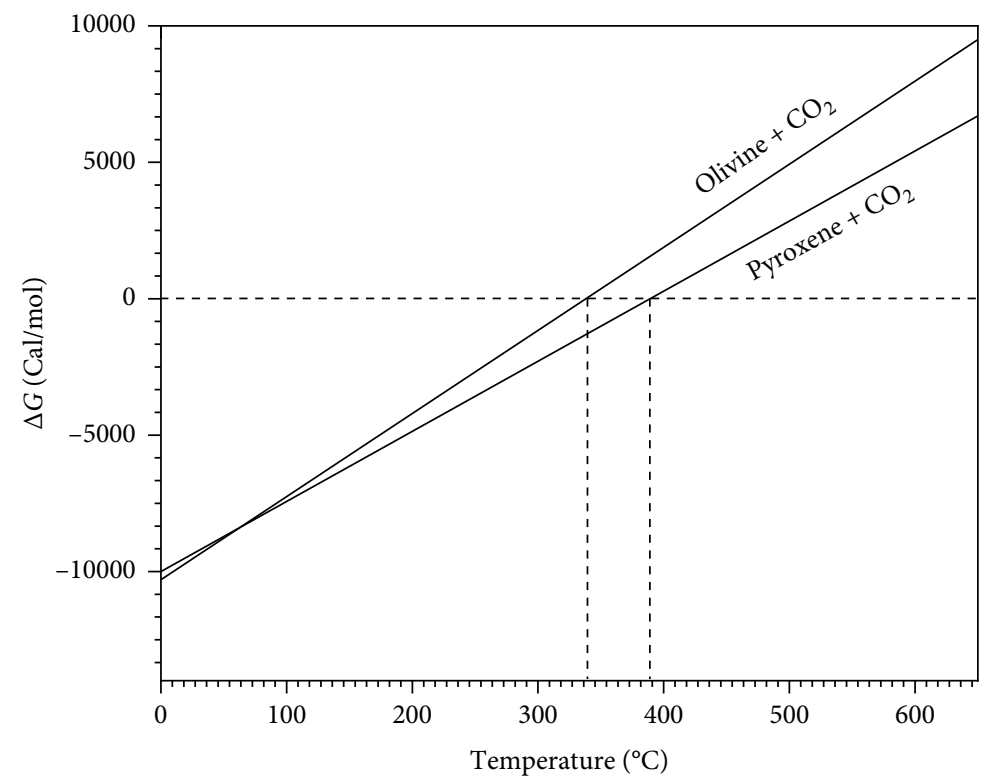

Figure 11: Temperature dependence of the Gibbs free energy of the carbonation of pyroxene and olivine $\left(f_{\text {co2 }}=100\right.$ bar; modified after Marini [41]).

temperature required for the reactions of albite and anorthite with $\mathrm{CO}_{2}\left(150^{\circ} \mathrm{C}-300^{\circ} \mathrm{C}\right)$ but lower than that of the reaction between pyroxene and olivine with $\mathrm{CO}_{2}$ (Figure 12). Because the mafic minerals are not fully carbonated, they can absorb most of the produced $\mathrm{CO}_{2}$ and plagioclase does not undergo carbonation.

5.2. Dike Clavization. Clavization primarily occurs at a distance of $0.5-0.7 \mathrm{~m}$ from the edge of the dike. In this band, the color of the sample turned pale yellow and the rock hardness decreased significantly. Microscopically, labradorite disappeared and the albite and kaolinite contents increased. In addition, the mafic minerals were completely altered to siderite and mixtures of chlorite and smectite group minerals.
According to Boles [42, 43], the alteration of plagioclase into clay may be attributed to the activity of pore water rich in $\mathrm{Na}^{+}$, which leads to the albitization of plagioclase. In this process, $\mathrm{Ca}^{2+}$ in labradorite is replaced by $\mathrm{Na}^{+}$to form albite, while redundant $\mathrm{Al}^{3+}$ forms clay minerals. When the magmatic rock intrudes in the coal, it cuts through the stratum and connects the water in the coal seam, roof, and floor, which would induce a localized convection cell and then resulting in an enhanced groundwater activity at the edges of the dike. Furthermore, high concentrations of $\mathrm{Na}^{+}$in the coal seam, roof, and floor water [44] may lead to a similar albitization process. The albitization reaction can be written as follows [42]:

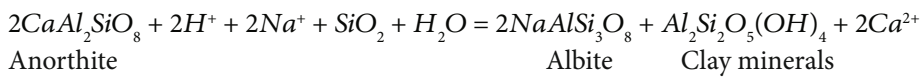




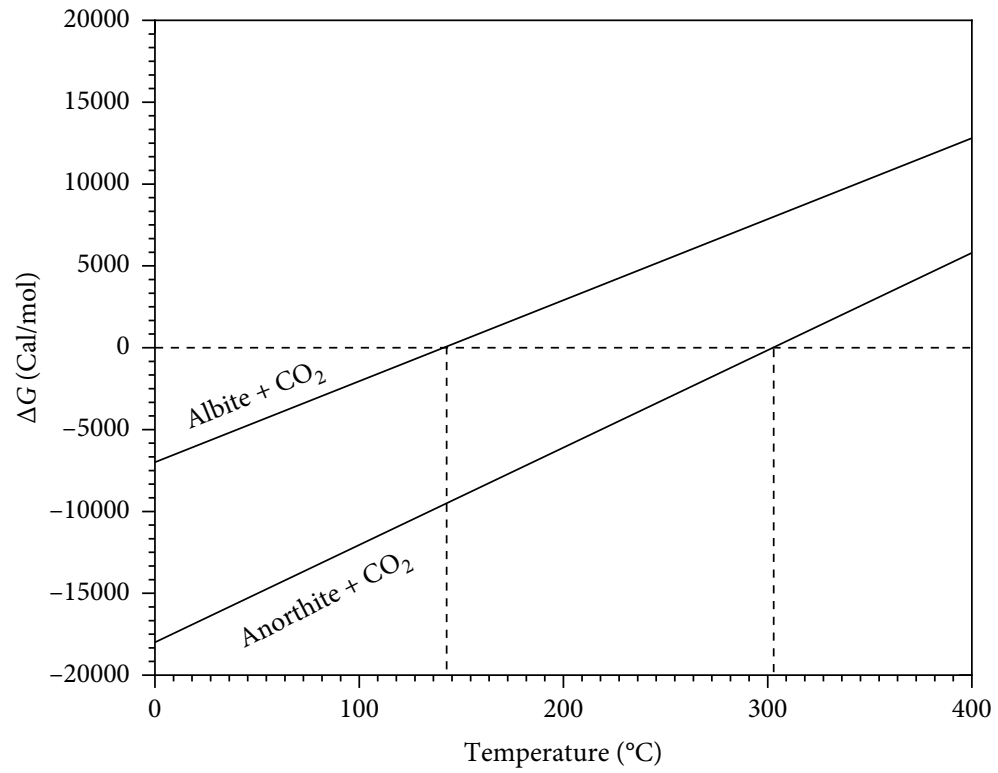

Figure 12: Temperature dependence of the Gibbs free energy of carbonation of albite and anorthite $\left(f_{\text {co2 }}=100\right.$ bar; modified after Marini [41]).

During the albitization of plagioclase, mafic minerals are also altered to chlorite. Several new alteration minerals, such as sericite, epidote, and iron oxides, are formed during this process [45]. Nermec suggested that albitization represents the intense alteration of mafic minerals [46]. Therefore, compared with plagioclase, mafic minerals are more prone to alteration to mixtures of the chlorite and smectite group minerals in the presence of groundwater. Some of the mafic minerals in the middle of the dike were altered to chlorite and smectite group minerals, which means that the underground water influenced the entire dike. The groundwater activity was the strongest at $0.5-$ $0.7 \mathrm{~m}$ from the edge of the dike, resulting in the albitization of labradorite and chloritization and smectitization of mafic minerals.

5.3. Dike Zoning. Based on the observation of carbonation and clavization in the dike, the dike first underwent carbonation during the condensation process and mafic minerals were altered to carbonate minerals (major carbonate mineral: Ca-bearing Mg-siderite) at the edge of the dike with a width of $1-1.5 \mathrm{~m}$. Subsequently, the groundwater activity affected the entire dike, causing different levels of chloritization and smectitization of the mafic minerals. At the edge of the dike with a width of $0.5-0.7 \mathrm{~m}$, intense groundwater activity led to the albitization of labradorite. Therefore, the dike can be divided into three bands, that is, a weak alteration band (weak chloritization and smectitization), carbonation band (carbonation, chloritization, and smectitization), and clavization band (albitization as domination, chloritization, smectitization, and carbonation), which correspond to the dark green, light green, and pale yellow bands in the macroscopic images, respectively. The different alteration processes that occur in the three bands are illustrated in the schematic diagram in Figure 13.

\section{Conclusions}

In this study, we employed several analytical techniques, including SEM, optical microscopy, and XRD, to evaluate the mineral alteration of intrusions in coal seams in the Datong coalfield, Shanxi, China. Our main conclusions are as follows:

(1) After magma intrudes the coal seam, in addition to differences in the degree alteration in the coal seams on both sides, the dike itself experiences an alteration zoning effect

(2) When magmatic rock intruded into the low-rank coal, the coal first released a large quantity of $\mathrm{CO}_{2}$. The mafic minerals in the intrusion reacted with the $\mathrm{CO}_{2}$, altering the mafic minerals into carbonate minerals (Ca-bearing $\mathrm{Mg}$-siderite, among others), that is, forming a carbonate band. Labradorite finds it more difficult to participate in the carbonation reaction when compared to mafic minerals and hence it remains mostly unaltered

(3) The magmatic intrusion destroyed the strata and connected the water in the coal seam, roof, and floor, resulting in an enhanced groundwater activity around the dike. At the edge of the dike, labradorite was altered to the albite and kaolin group minerals. Mafic minerals were altered to mixtures of chlorite and smectite group minerals to different degrees under the action of groundwater. The edge of the dike experienced the highest degree of 


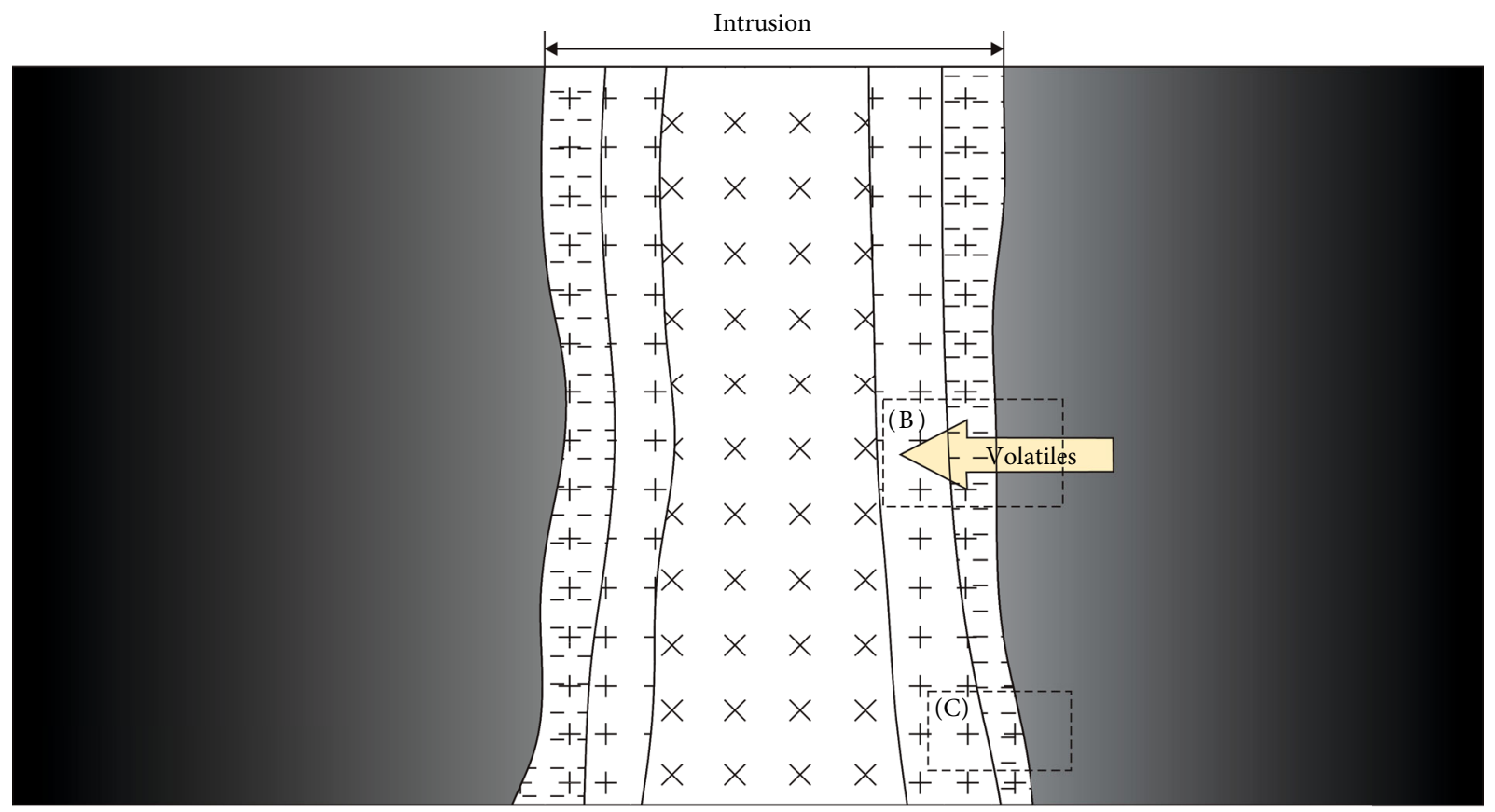

(a)

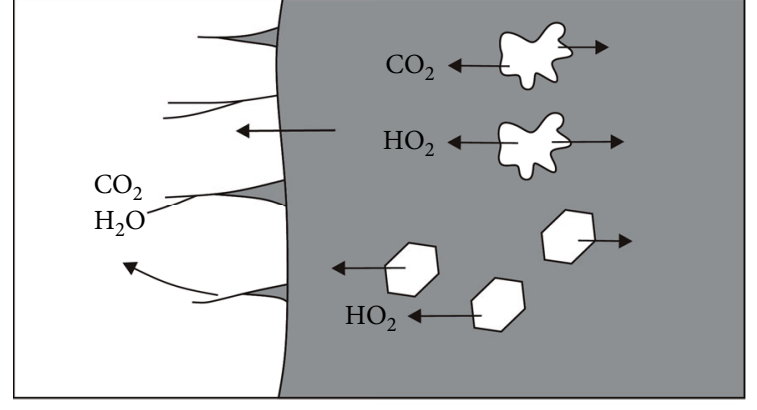

(b)

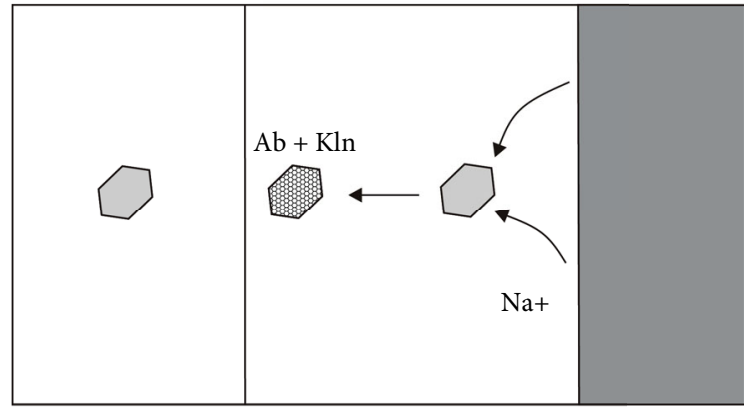

(c)

\begin{tabular}{|c|c|}
\hline & Natural coke and coal \\
\hline & Clavization band \\
\hline & Natural coke \\
\hline $\begin{array}{r}x \times 1 \\
\end{array}$ & Weak alteration band \\
\hline & Carbonation band \\
\hline
\end{tabular}

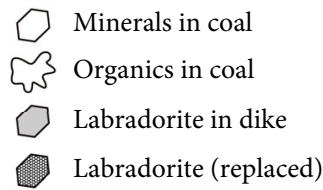

Figure 13: (a) Schematic of the intrusion alteration in the dike. (b) Carbonation of mafic minerals when volatiles are released from the organics and minerals in the coal. (c) Albitization of plagioclase. Labradorite is replaced by albite and kaolin group minerals.

alteration. A weak alteration band and a clavization band formed due to the groundwater activity

This study sheds light on the alteration mechanisms, and the findings support the mineralogical analysis and prediction of different coal seams. Understanding the mechanisms of alteration in igneous intrusions in coal seams will help to predict and analyze the mineralogical characteristics of coal seams.

\section{Data Availability}

The mineralogical, petrographic, and coal quality data used to support the findings of this study are included in the article.

\section{Conflicts of Interest}

The authors declare that there are no conflicts of interest regarding the publication of this paper.

\section{Acknowledgments}

This research was supported by the National Key Basic Research and Development Program (2017YFB0603101), and the National Natural Science Foundation of China (41802191). The authors would like to thank Professor Robert Finkelman, Dr. David French, and Professor Shaoqing Wang for their help with the coal analyses; Professor Anchao Zhou for his help with the mineralogical analyses; 
and Dr. Ian T. Graham for his suggestions regarding the alteration mechanisms. The authors are grateful for Editage's editorial support.

\section{Supplementary Materials}

Figure 14: (a) a narrow diabase dike (60 cm wide, yellow) in the Xiaoyu coal mine, Datong coalfield. Photomicrographs of (b) PPL and (c) XPL of this dike. Plagioclase crystals were completely altered to clay minerals, while augite and olivine were altered to carbonate minerals and chlorite. Figure 15: (a) a diabase dike (pale gray) in the Wajinwan coal mine, Datong coalfield. Photomicrographs of (b) PPL and (c) XPL of this dike. Plagioclase crystals were completely altered to clay minerals, while augite and olivine were altered to carbonate minerals and chlorite. Figure 16: a diabase dike (pale yellow) in the Jinzhuang coal mine, Datong coalfield. Figure 17: a diabase sill (pale gray) in the Dongzhouyao coal mine, Datong coalfield. Figure 18: a lamprophyre dike (dark green to dark gray) in Emaokou, Datong coalfield. Photomicrographs of (b) PPL and (c) XPL of this dike. For lamprophyric texture, the minerals were not seriously altered. (Supplementary Materials)

\section{References}

[1] R. B. Finkelman, N. H. Bostick, F. T. Dulong, F. E. Senftle, and A. N. Thorpe, "Influence of an igneous intrusion on the inorganic geochemistry of a bituminous coal from Pitkin County, Colorado," International Journal of Coal Geology, vol. 36, no. 3-4, pp. 223-241, 1998.

[2] J. R. Cooper, J. C. Crelling, S. M. Rimmer, and A. G. Whittington, "Coal metamorphism by igneous intrusion in the Raton Basin, CO and NM: implications for generation of volatiles," International Journal of Coal Geology, vol. 71, no. 1, pp. 1527, 2007.

[3] S. M. Rimmer, L. E. Yoksoulian, and J. C. Hower, "Anatomy of an intruded coal, I: Effect of contact metamorphism on wholecoal geochemistry, Springfield (No. 5) (Pennsylvanian) coal, Illinois Basin," International Journal of Coal Geology, vol. 79, no. 3, pp. 74-82, 2009.

[4] H. J. Kisch and G. H. Taylor, "Metamorphism and alteration near an intrusive-coal contact," Economic Geology, vol. 61, no. 2, pp. 343-361, 1966.

[5] H. J. Kisch, "Carbonization of semi-anthracitic vitrinite by an analcime basanite sill," Economic Geology, vol. 61, no. 6, pp. 1043-1063, 1966.

[6] C. R. Ward, P. R. Warbrooke, and F. I. Roberts, "Geochemical and mineralogical changes in a coal seam due to contact metamorphism, Sydney Basin, New South Wales, Australia," International Journal of Coal Geology, vol. 11, no. 2, pp. 105-125, 1989.

[7] Y. Yao, D. Liu, and W. Huang, "Influences of igneous intrusions on coal rank, coal quality and adsorption capacity in Hongyang, Handan and Huaibei coalfields, North China," International Journal of Coal Geology, vol. 88, no. 2-3, pp. 135-146, 2011.

[8] J. Chen, G. Liu, H. Li, and B. Wu, "Mineralogical and geochemical responses of coal to igneous intrusion in the Pansan coal mine of the Huainan coalfield, Anhui, China,"
International Journal of Coal Geology, vol. 124, pp. 11-35, 2014.

[9] A. K. Singh, M. Sharma, and M. P. Singh, "SEM and reflected light petrography: a case study on natural cokes from seam XIV, Jharia coalfield, India," Fuel, vol. 112, pp. 502-512, 2013.

[10] A. K. Singh, M. Sharma, and M. P. Singh, "Genesis of natural cokes: some Indian examples," International Journal of Coal Geology, vol. 75, no. 1, pp. 40-48, 2008.

[11] A. K. Singh, M. P. Singh, M. Sharma, and S. K. Srivastava, "Microstructures and microtextures of natural cokes: a case study of heat-affected coking coals from the Jharia coalfield, India," International Journal of Coal Geology, vol. 71, no. 2-3, pp. 153-175, 2007.

[12] X. Niu, B. Chen, G. Feng, F. Liu, and J. Yang, "Origin of lamprophyres from the northern margin of the North China Craton: implications for mantle metasomatism," Journal of the Geological Society, vol. 174, no. 2, pp. 353-364, 2017.

[13] J. Shao and L. Zhang, "Mesozoic dyke swarms in the north of North China," Acta Petrologica Sinica, vol. 18, no. 3, pp. 312-318, 2002.

[14] J. Shao, Y. Zhang, L. Zhang, B. Mu, P. Wang, and F. Guo, "Early Mesozoic dike swarms of carbonatites and lamprophyres in Datong area," Acta Petrologica Sinica, vol. 19, no. 1, pp. 93-104, 2003.

[15] L. Shen, F. CaiXia, J. BoMing, H. RuiZhong, Z. MingGuo, and L. ShaoCong, "Zircon U-Pb age, geochemical, and Sr$\mathrm{Nd}$ isotopic constraints on the origin of Late Carboniferous mafic dykes of the North China Craton, Shanxi Province, China," Acta Petrologica Sinica, vol. 30, no. 6, pp. 17071717, 2014.

[16] G. M. Dou, Datong Coalfield Carboniferous-Permian Coal Seam Occurrence Characteristics and Control Effects, Taiyuan University of Technology, Taiyuan, China, 2013.

[17] D. N. Liu, The Coupling Relationship of Coal Metamorphism and Sedimentary Tectonic Magmatic Activities for Datong Double Period Coal-Bearing Basin, Taiyuan University of Technology, Taiyuan, China, 2015.

[18] D. Liu, A. Zhou, and Z. Chang, "Geochemistry characteristics of major and rare earth elements in No. 8 raw and weathered coal from Taiyuan Formation of Datong Coalfield," Journal of China Coal Society, vol. 40, pp. 422-430, 2015.

[19] Y. Yuan, S. Tang, S. Zhang, and N. Yang, "Mineralogical and geochemical characteristics of trace elements in the Yongdingzhuang Mine, Datong Coalfield, Shanxi Province, China," Minerals, vol. 8, no. 7, p. 297, 2018.

[20] Y. Yuan, S. Tang, and S. Zhang, "Geochemical and mineralogical characteristics of the Middle Jurassic coals from the Tongjialiang Mine in the Northern Datong Coalfield, Shanxi Province, China," Minerals, vol. 9, no. 3, p. 184, 2019.

[21] D. Liu, A. Zhou, and M. Ma, "Coal facies characteristics of No. 5 coal seam in Baidong Mine Area, Datong Coalfield," Coal Geology of China, vol. 23, pp. 1-4, 2011.

[22] B. Chen, B. Jahn, and W. Tian, "Evolution of the Solonker suture zone: Constraints from zircon $\mathrm{U}-\mathrm{Pb}$ ages, $\mathrm{Hf}$ isotopic ratios and whole-rock $\mathrm{Nd}-\mathrm{Sr}$ isotope compositions of subduction- and collision-related magmas and forearc sediments," Journal of Asian Earth Sciences, vol. 34, no. 3, pp. 245-257, 2009.

[23] "Method of Determining Microscopically the Reflectance of Vitrinite in Coal," 2008, GB/T 6948-2008. 
[24] "Proximate Analysis of Coal," 2008, GB/T212-2008.

[25] "Ultimate Analysis of Coal," 2001, GB/T476-2001.

[26] "Test Method for Moisture in the Analysis Sample of Coal and Coke," 2011.

[27] "Standard Method for Ash in the Analysis Sample of Coal and Coke," 2004, 3174-04.

[28] "Test Method for Volatile Matter in the Analysis Sample of Coal and Coke," 2011.

[29] "Standard Test Methods for Carbon and Hydrogen in the Analysis Sample of Coal and Coke," 2002.

[30] M. J. L. Bas and A. L. Streckeisen, "The IUGS systematics of igneous rocks," Journal of the Geological Society, vol. 148, no. 5, pp. 825-833, 1991.

[31] "Standard Classification of Coals by Rank," 2005.

[32] I. Aarnes, H. Svensen, J. A. D. Connolly, and Y. Y. Podladchikov, "How contact metamorphism can trigger global climate changes: modeling gas generation around igneous sills in sedimentary basins," Geochimica et Cosmochimica Acta, vol. 74, no. 24, pp. 7179-7195, 2010.

[33] I. Aarnes, Y. Podladchikov, and H. Svensen, "Devolatilizationinduced pressure build-up: implications for reaction front movement and breccia pipe formation," Geofluids, vol. 12, no. 4, 279 pages, 2012.

[34] J. Hunt, Petroleum Geochemistry and Geology Freeman, San Francisco, 1979.

[35] E. Stach, Stach's Textbook of Coal Petrology, 1982.

[36] T. C. Chamberlin and R. D. Salisbury, Introductory Geology: A Text-Book for Colleges, H. Holt, Ed., 1914.

[37] M. Mastalerz, A. Drobniak, and A. Schimmelmann, "Changes in optical properties, chemistry, and micropore and mesopore characteristics of bituminous coal at the contact with dikes in the Illinois Basin," International Journal of Coal Geology, vol. 77, no. 3-4, pp. 310-319, 2009.

[38] A. Quaderer, M. Mastalerz, A. Schimmelmann, A. Drobniak, D. L. Bish, and R. P. Wintsch, "Dike-induced thermal alteration of the Springfield Coal Member (Pennsylvanian) and adjacent clastic rocks, Illinois Basin, USA," International Journal of Coal Geology, vol. 166, pp. 108-117, 2016.

[39] A. Sanna, M. Uibu, G. Caramanna, R. Kuusik, and M. M. Maroto-Valer, "A review of mineral carbonation technologies to sequester CO2," Chemical Society Reviews, vol. 43, no. 23, pp. 8049-8080, 2014.

[40] P. B. Kelemen and J. Matter, "In situ carbonation of peridotite for $\mathrm{CO}_{2}$ storage," Proceedings of the National Academy of Sciences, vol. 105, no. 45, pp. 17295-17300, 2008.

[41] L. Marini, Geological Sequestration of Carbon Dioxide: Thermodynamics, Kinetics, and Reaction Path Modeling, Elsevier, 2006.

[42] J. R. Boles, "Active albitization of plagioclase, gulf coast tertiary," American Journal of Science, vol. 282, no. 2, pp. 165180, 1982.

[43] K. Ramseyer, J. R. Boles, and P. C. Lichtner, "Mechanism of plagioclase albitization," Journal of Sedimentary Research, vol. 62, no. 3, pp. 349-356, 1992.

[44] I. Hamawand, T. Yusaf, and S. G. Hamawand, "Coal seam gas and associated water: a review paper," Renewable and Sustainable Energy Reviews, vol. 22, pp. 550-560, 2013.
[45] G. H. Anderson, "Granitization, albitization, and related phenomena in the northern Inyo Range of California-Nevada," Bulletin of the Geological Society of America, vol. 48, no. 1, pp. 1-74, 1937.

[46] D. Němec, "Plagioclase albitization in the lamprophyric and lamproid dykes at the eastern border of the Bohemian Mass," Contributions to Mineralogy and Petrology, vol. 12, no. 4, pp. 340-353, 1966. 